\title{
Computing and engineering students' perceptions of entrepreneurship education in a Jamaican university
}

\author{
Lisa Facey-Shaw; Danielle Mcken; Kemar Warren; Dillon Young; Hylton McDonald; \\ lshaw@utech.edu.jm, mckendanielle@gmail.com, kemarwarren06@gmail.com, dillonyoung041@gmail.com, \\ hyltonmcdonald@gmail.com, \\ University of Technology, Jamaica
}

\begin{abstract}
Entrepreneurship fosters growth and competitiveness in a country's economy. University students, especially those in the technical fields, have the potential to found high growth technological-based innovative ventures. This paper looks at student perceptions of entrepreneurship education among undergraduate computing and engineering students at the University of Technology, Jamaica as a first step in fostering entrepreneurial intentions. Students appear to have limited exposure to entrepreneurial education which can affect their entrepreneurial intentions and reduce their inclination to start a business. Implications are that deliberate formal and informal curriculum activities should be instituted to promote innovation and entrepreneurship among computing and engineering students so that their technical education can lead to greater participation in entrepreneurial programs and activities. The significance is that increased participation among this group can result in technologically based businesses which can address the human capital gap in the Latin American and Caribbean region.
\end{abstract}

Keywords-Entrepreneurship education, entrepreneurial intentions, computing and engineering, Jamaica

\section{INTRODUCTION}

It is widely accepted that entrepreneurship drives and fosters economic growth and development [1]. Through the discovery and exploitation of opportunities within existing or by creating new organizations [2], entrepreneurs contribute to a country's competitiveness by facilitating or creating new jobs and engaging in the development of innovative products and services. It is therefore crucial to prepare and develop the human capital necessary to create the transformations that will lead to new markets, products, firms and technologies [3]. In a recent report on the Latin American and Caribbean (LAC) region [1], it was found that despite the existence of many entrepreneurs, firms in the region suffer from low levels of innovation with the human capital gap - particularly a lack of scientists and engineers - highlighted as one of the fundamental contributing factors to this problem.

Universities have an important role to play in providing the infrastructure and skill sets for developing entrepreneurship [4]. This responsibility should take on greater significance for technical students who are expected to innovate, bring to market new technologies and create high growth ventures which can stimulate economic growth [5], [6]. [3] highlights the disparity between universities in developed countries which teach and invest in engineering

Digital Object Identifier (DOI):

http://dx.doi.org/10.18687/LACCEI2019.1.1.452

ISBN: 978-0-9993443-6-1 ISSN: 2414-6390 entrepreneurship and other tenets of technological progress compared to those in the LAC region. The author suggests that through fostering entrepreneurship, creativity and other skills, engineers have the potential to develop new technology which is key for economic growth and innovation. Re-examining the curriculum of LAC countries to promote and expand scientific and engineering training at the secondary and tertiary levels [1] and incorporating design, innovation and entrepreneurship in the curriculum of future engineers [3] may help to alleviate the gap. Creativity and innovativeness, attributes necessary for the entrepreneurial process, can also be found within the computing industry, given its dynamic nature; hence infusing entrepreneurship education in the computing curriculum can also lead to computing students starting innovative, technological ventures [7].

Though a number of studies on entrepreneurial intentions exists, the literature has been limited in developing countries [8] and even more so within the Caribbean region. In responding to this gap in literature as well as the human capital gap in the region [1], this study focuses on the role of entrepreneurial education in fostering the entrepreneurial intentions of computing and engineering students of UTech, Jamaica. It should be noted that the university has a School of Entrepreneurship, Ethics and Leadership, however, the focus of this work is on the computing and engineering students who, as earlier mentioned, are expected to engage in high growth ventures.

Given the potential role entrepreneurship can play in contributing to the well-needed economic development of the region, the findings of this study are of significance to university administrators of computing and engineering programmes. Examining the entrepreneurial intentions of university students may help in understanding the factors that lead to, or have the potential to lead to, their entrepreneurial behavior. This study can also serve as evidence-based research to assist in academic policy decision-making regarding entrepreneurial education for university students.

Whereas the overall study examined various factors influencing entrepreneurial intentions among computing and engineering students at the University of Technology, Jamaica, the primary purpose of this paper is to examine student perceptions of entrepreneurship education as a single factor and whether it motivates them towards entrepreneurial intentions to start a business.

The ensuing sections will examine the general literature on entrepreneurial intentions and the role of entrepreneurship education. The methodology undertaken for this research will

$17^{\text {th }}$ LACCEI International Multi-Conference for Engineering, Education, and Technology: "Industry, Innovation, And Infrastructure for Sustainable Cities and Communities", 24-26 July 2019, Jamaica. 
then be outlined and the results presented and discussed in light of existing literature. Recommendations and the conclusion will then be presented, along with suggestions for future work.

\section{ENTREPRENEURIAL INTENTIONS AND ENTREPRENEURSHIP EDUCATION}

Entrepreneurial intentions can be defined as the state of mind of entrepreneurs which direct their attention toward founding a business [9]. Studying entrepreneurial intentions provides insights into factors that influence why individuals consider starting a business rather than evaluating the characteristics of existing entrepreneurs which can help to determine policy measures that can stimulate entrepreneurship [10]. [1] suggests that there is limited overlap between the human capital for entrepreneurship and innovation with general curricula, and considers it worthy to examine scientific and engineering training in the LAC region. Examining the entrepreneurial intentions of university students in the LAC region within these fields could serve to stimulate regional policy to boost the capacity for innovation and entrepreneurship.

Studies of entrepreneurial intentions are rooted in the theory of planned behaviour [11] which reasons that attitudes towards behaviours such as entrepreneurship actions, subjective norms or perceived social pressure which may cause one to carry out or not carry out the behaviour, and perceived behavioural control or how easy or difficult it is to perform the behaviour based on past or anticipated experiences, can predict intentions. The theory also finds that intentions and perceived behavioural control (self-efficacy) predict behaviour [11]. A study by [12] concluded that Ajzen's three factors of entrepreneurial intentions, attitudes, perceived social value and perceived self-efficacy explained and influenced entrepreneurial behaviour in Latin America, however there was a negative relationship between the perception of social value and entrepreneurial intention.

Planned behaviour, such as entrepreneurship, is often examined through intentions models which look at the antecedents of intention which help to explain and predict entrepreneurial activity [13]. The emergent model by [14] posits perceived desirability and perceived feasibility as factors leading to intention to starting a business, along with an individual's propensity to act and a precipitating event (displacement) which propels actions leading to the creation of a venture.

Several factors have emerged in the literature as determinants of entrepreneurial intentions. Our focus here is on entrepreneurship education which various authors concur contributes positively to entrepreneurial intention [4], [15], [16]. Caribbean educators are encouraged to focus on helping students to perceive entrepreneurship as desirable and feasible through entrepreneurs sharing their experiences in the classroom, facilitating internship opportunities for students and helping students to see themselves as competent in overcoming the challenges associated with starting a business [17]. This is supported by [16] who encourage universities to intensify entrepreneurship programmes and improve the image of entrepreneurship as a career option. The Global Entrepreneurship Monitor (GEM) Jamaica report of 2016/7 recommends that an entrepreneurship culture should be promoted among secondary level students to stimulate their interest in entrepreneurship and that universities should develop short courses to provide individuals with formal training in entrepreneurship.

Various approaches have been used to integrate entrepreneurship into the curriculum for technical students, including specialized courses, for example, Technology Entrepreneurship for Engineers and Computer Scientists [18]; concentration and optional programs in leadership and innovation spanning a number of courses [7]; seminars and presentations on entrepreneurial experiences [7]. Recommendations to foster entrepreneurship among engineering university students include start-up exhibitions of successful entrepreneurs as role models, workshops on idea generation and business plan creation, and inter-university business plan competitions [4], and the inclusion of more female entrepreneurs as role models [8]. [19] found a deterioration in Greek university students' entrepreneurial intentions and aspirations during their four-year studies and that faculty perspectives do not encourage the promotion of entrepreneurial mindsets among students. The author however highlighted the Greek economic context which may have impacted on the perceptions of faculty. It has been suggested by [20] that while entrepreneurship programmes may increase the likelihood of success, inspiration from instructors can encourage higher entrepreneurial intention. [15] also recommends the employment of specific teaching strategies to enhance entrepreneurial intention.

Several factors have emerged in the literature as determinants of entrepreneurial intentions. However, our focus at this time is on entrepreneurship education and the influence it has on computing and engineering students' participation in activities which can lead to entrepreneurship. We have taken entrepreneurship education in its broadest context to include formal and informal courses, activities and programs geared towards stimulating entrepreneurship.

\section{METHODOLOGY}

A quantitative survey approach was adopted to examine, among other factors, entrepreneurship education as a factor influencing the entrepreneurial intentions of computing and engineering students at the University of Technology, Jamaica (UTech). Participants included upper level students (from $3^{\text {rd }}$ year up) from the School of Computing and Information Technology (SCIT) and the School of Engineering (SOE) at the University of Technology, Jamaica. Both Schools comprise

Digital Object Identifier: (to be inserted by LACCEI)

ISSN, ISBN: (to be inserted by LACCEI).

$17^{\text {th }}$ LACCEI International Multi-Conference for Engineering, Education, and Technology: "Industry, Innovation, And Infrastructure for Sustainable Cities and Communities”, 24-26 July 2019, Jamaica. 
the Faculty of Engineering and Computing. Some questions in the instrument were adapted and slightly modified from various sources [21], [22], [23]. The questionnaire included demographics as well as Likert-type statements related to entrepreneurial factors ranging from 1-Strongly Agree to 5Strongly Disagree.

Prior to distributing the questionnaires, a pilot test was conducted with 10 students from the target population to assess questionnaire clarity and length. To distribute the questionnaires, hyperlinks were provided to the online questionnaire via existing online communication groups (SCIT and Engineering). Intercept surveys [25] were also conducted by the researchers who strolled around campus with the questionnaire on a mobile device. By asking students questions such as "Are you in SCIT or Engineering?" and "What year are you in?" the researchers were able to quickly identify suitable participants. Data was collected over a two-week period at the end of which 250 survey responses were completed.

Descriptive statistics have been used to analyze the data relating to entrepreneurship education and student participation in entrepreneurial activities. The results have been presented in the form of tables, graphs and charts. The results are discussed below.

\section{FINDINGS AND DISCUSSION}

Demographic analysis of students (Fig. 1 and Fig. 2) reveal that $56 \%$ belong to the School of Computing and Information Technology with the remaining $44 \%$ belonging to the School of Engineering. The majority of the sample overall are male and most students $(n=182)$ are in the 18-24 years category with the next largest age group in the 25-29 years category $(n=61)$ The majority of the students surveyed were in the fourth year of their programme. It is important to note that Bachelor's students in their fifth year and above are those who are either studying part-time, had previously taken some time off from their studies or whose normal academic progression have otherwise been delayed.

\begin{tabular}{|c|c|c|c|}
\hline Levels & Counts & $\%$ of Total & Cumulative \% \\
\hline Engineering & 110 & $44.0 \%$ & $44.0 \%$ \\
\hline SCIT & 140 & $56.0 \%$ & $100.0 \%$ \\
\hline \multicolumn{4}{|c|}{ Frequencies of Age } \\
\hline Levels & Counts & $\%$ of Total & Cumulative \% \\
\hline $18-24$ years & 182 & $72.8 \%$ & $72.8 \%$ \\
\hline $25-29$ years & 61 & $24.4 \%$ & $97.2 \%$ \\
\hline 30 - 34 years & 4 & $1.6 \%$ & $98.8 \%$ \\
\hline $35-39$ years & 2 & $0.8 \%$ & $99.6 \%$ \\
\hline Below 18 years & 1 & $0.4 \%$ & $100.0 \%$ \\
\hline
\end{tabular}

Fig. 1 Distribution of students based on School and Age

\begin{tabular}{|c|c|c|c|c|}
\hline Levels & Counts & $\%$ of Total & Cumulative \% & \\
\hline Female & 76 & $30.4 \%$ & $30.4 \%$ & \\
\hline Male & 174 & $69.6 \%$ & $100.0 \%$ & \\
\hline \multicolumn{5}{|c|}{ Frequencies of Year } \\
\hline \multicolumn{2}{|c|}{ Levels } & Counts & $\%$ of Total & Cumulative \% \\
\hline \multicolumn{2}{|c|}{ Fifth year and above } & 58 & $23.2 \%$ & $23.2 \%$ \\
\hline \multicolumn{2}{|c|}{ Fourth year } & 118 & $47.2 \%$ & $70.4 \%$ \\
\hline \multicolumn{2}{|c|}{ Third year } & 74 & $29.6 \%$ & $100.0 \%$ \\
\hline
\end{tabular}

Fig.2 Distribution of students based on Gender and Year

Table 1 shows that approximately $14 \%$ of the students included in the sample have never been taught entrepreneurship in any of their modules or seminars, however for the remaining $86 \%(\mathrm{n}=216)$, most students have been taught an entrepreneurship course within their fourth year $(n=103)$. An Entrepreneurship course is required for all students, however the year in which the course is scheduled varies among the programmes in SCIT or SOE.

TABLE I

DISTRIBUTION OF STUDENTS WHO HAVE BEEN TAUGHT AN ENTREPRENEURSHIP COURSE

\begin{tabular}{llrrrr}
\multicolumn{2}{l}{ Frequencies of TaughtEntrep } \\
\hline \multirow{2}{*}{ TaughtEntrep } & School & $\begin{array}{c}\text { Fifth year and } \\
\text { above }\end{array}$ & Fourth year & Third year & Total \\
\cline { 3 - 6 } Yes & Engineering & 16 & 43 & 28 & 87 \\
& SCIT & 36 & 60 & 33 & 129 \\
\cline { 3 - 6 } & Engineering & 52 & 103 & 61 & 216 \\
\multirow{2}{*}{ No } & 3 & 12 & 8 & 23 \\
& SCIT & 3 & 3 & 5 & 11 \\
\cline { 2 - 6 } & & 6 & 15 & 13 & 34 \\
\hline
\end{tabular}

Students were also asked to indicate, if they were interested in starting a business, the extent to which the business would utilize aspects of their course of study (1- No Extent, 2 - Low Extent, 3 - Moderate Extent, 4 - Great Extent, 5 - Not Applicable). A mean score of 3.56 (median $=4$ ) was recorded based on their responses, indicating that students consider some information from their course useful should they start a business.

When asked to examine their involvement in the studentbased entrepreneurship club and the business model competition hosted on the university campus, it was revealed that only $6 \%$ of students attended the club and approximately $15 \%$ participated in a business model competition session. These results indicate that outside of the formal course on entrepreneurship, computing and engineering students do not appear to be gaining additional information on becoming entrepreneurs through these informal activities.

Responding to statements such as whether they perceived that the entrepreneurship education received at UTech

$17^{\text {th }}$ LACCEI International Multi-Conference for Engineering, Education, and Technology: "Industry, Innovation, And Infrastructure for Sustainable Cities and Communities", 24-26 July 2019, Jamaica. 
complements their professional background and that they have gained sufficient knowledge to allow them to start a business [24], computing and engineering students appeared to be mostly neutral or in some instances, disagreed with the statements (for e.g. that entrepreneurship education is effective at UTech). Given that these students typically only pursue one formal course on Entrepreneurship and do not appear to participate in the few clubs or informal activities which promote entrepreneurship, this is not surprising. Students also appear to disagree that they are actively encouraged or prepared to start an entrepreneurial career. Given the literature earlier discussed in which various authors consider entrepreneurship education as a positive contribution to entrepreneurial intentions [4], [15], [16], these results indicate that limited exposure to entrepreneurship education could by the same argument have a negative contribution on students' inclination to start a business.

Computing and engineering students' responses on the effectiveness of entrepreneurship at UTech (Fig. 3) reveal that only $39 \%$ in total $(\mathrm{SCIT}=56, \mathrm{SOE}=41, \mathrm{n}=97)$ either agree or strongly agree that entrepreneurship education is effective at UTech whereas the remaining $61 \%$ are either neutral or disagree that the education is effective. More SCIT students than SOE students either disagree $(n=37)$ or agree $(n=33)$ with this statement.

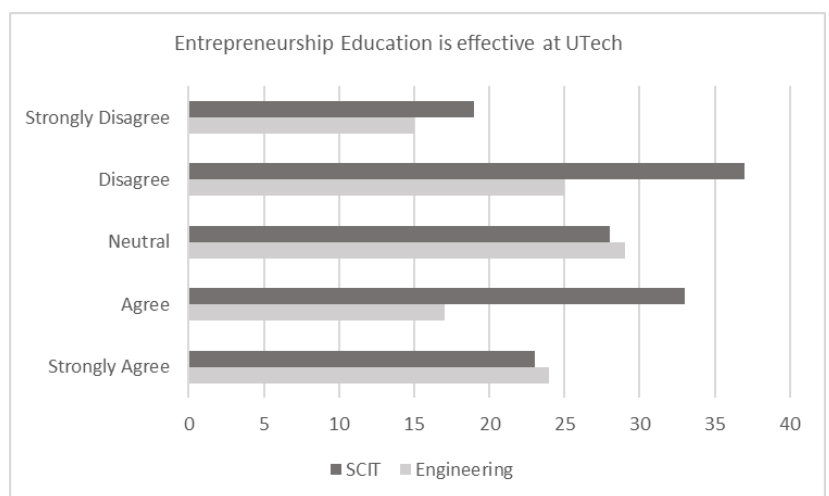

Fig. 3 Responses on the effectiveness of entrepreneurship at UTech

Similar mostly neutral results $(\mathrm{M}=3.43)$ were obtained for students' motivation to start businesses based on their participation in business plan or internship programs [22]. When asked whether entrepreneurship courses prepared persons well for an entrepreneurial career (Fig 4), over $80 \%$ of computing and engineering students were either neutral or disagreed with the statement. It may be perceived that were it not for the students' field of study, these results would be significantly different, for example, students pursuing business or entrepreneurship programmes would perhaps be more motivated and would have encountered far many more courses that could be considered as leading to their inclinations to start businesses. The premise of this article, however, is that if computing and engineering students are to significantly transform the economy through high-growth businesses, more will need to be done to educate the students according to encourage their entrepreneurial intentions. One also needs to consider that there could be other factors such as selfmotivation, personality and willingness to take risks that could be present in these students hence they could still engage in start-up ventures. However, as the GEM Jamaica (2016/7) report and other researchers have suggested, a deliberate effort should be made to provide adequate formal training in entrepreneurship so that the university, in particular the Faculty of Engineering and Computing, can play its role in encouraging computing and engineering students' inclination to start businesses.

The question arises as to how much formal entrepreneurial training can be effectively integrated within existing computing and engineering curricula. In [7], the models of entrepreneurship within the computer science and computer engineering curricula includes a breadth approach where students are exposed to entrepreneurship to increase their awareness and opportunity identification, as well as a depth approach for aspiring entrepreneurs to provide greater coverage of business and finance components. It can be argued that the existing Entrepreneurship course delivered to the computing and engineering students serves as the main vehicle for providing awareness to students within SCIT and SOE, however more formal training is necessary to those students who may actively want to pursue entrepreneurship. Given the implications of merely expanding the number of credits in the curriculum, one recommendation is for the design of at least one additional elective course within the Schools which moves the student from the ideation stage to that of implementation within a high impact environment. The practical nature of such a course should be such that the student can actually register the business upon completion of the course. Alternatively, the capstone project that students engage in within their final year could be modified to reflect similar outcomes.

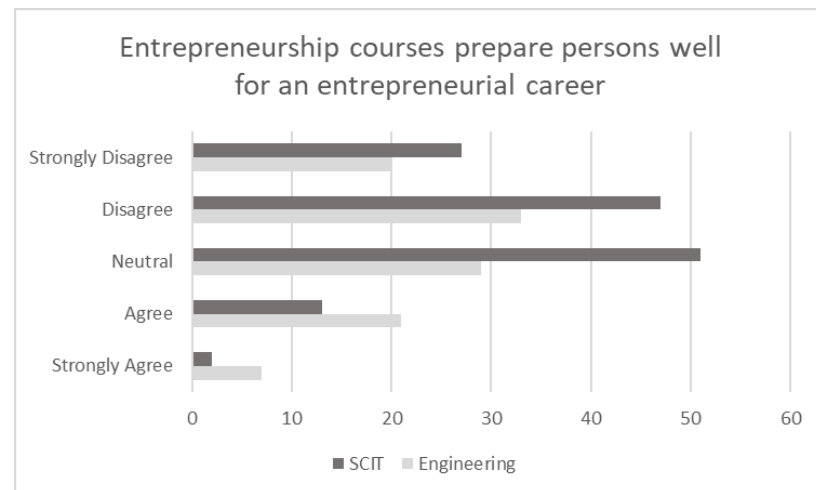

Fig. 4 Responses on whether entrepreneurship courses prepared persons well for an entrepreneurial career

$17^{\text {th }}$ LACCEI International Multi-Conference for Engineering, Education, and Technology: "Industry, Innovation, And Infrastructure for Sustainable Cities and Communities”, 24-26 July 2019, Jamaica. 
A report by the European Commission [26] recommends building effective entrepreneurship education with emphasis placed on active learning methods such as case studies and team activities to foster entrepreneurship in higher education. It may be that in the case of UTech, there are several courses which offer several assignments or activities which focus on case studies or team-building but overall it appears there is little integration of entrepreneurship throughout the curriculum of the technical students or students do not perceive these activities in this way. Distinctively specifying entrepreneurial activities may help to improve the perception among students on how the curriculum addresses entrepreneurship.

The report by [26] also recommends having experienced effective educators, commitment from university management, and creating linkages with industry professionals. As earlier mentioned, inspiration from instructors can encourage higher entrepreneurial intention [20]. It may be that individual faculty members encourage students towards entrepreneurship; however, a more structured approach would lead to greater outcomes for entrepreneurial careers. Initiatives such as having faculty members partner with industry for academic internships can also serve to give faculty industry insights that can be passed on to students. Concerted efforts should also be made to infuse entrepreneurship as a solid theme throughout the curriculum instead. Strategies could be designed [15] to have industry guest seminars or to actively use methods suggested by [26] to enhance entrepreneurial intention. Intrafaculty competitions could be designed to stimulate interest among the computing and engineering students.

Many technologically based university-related businesses have been founded by graduates and faculty with high percentages of employment and annual sales [16]. An additional recommendation is for special clubs to be created to help foster the entrepreneurship skills of computing and engineering students by helping to spark locally needed environments similar to Silicon Valley which would stimulate economic growth. [8] supports the strengthening of entrepreneurship education for undergraduate technological majors and recommends a focus on technology entrepreneurship as a targeted activity for this group. Implementing new curriculum courses and activities directly related to technology entrepreneurship would benefit the students. Formal courses in technology entrepreneurship [18] are also recommended, especially for those who are serious about entrepreneurship.

Further investigation into the work will allow us to explore the factors leading to entrepreneurial inclinations among students and to examine their significance in light of prevailing literature. This paper shows that there is a relationship between entrepreneurship education and intentions to start a business, albeit revealing that limited entrepreneurship education may lead to reduce students' inclination to want to start a business. The implications of this study are that deliberate formal and informal curriculum activities should be instituted to promote innovation and entrepreneurship among computing and engineering students so that their technical education can result in technologically based businesses to address the human capital gap in the Latin American and Caribbean region [1].

We, however, conclude our discussion in this section on a note of caution. The study in [27] concluded that the entrepreneurship track established at tertiary education institutions in Tunisia to foster a culture of entrepreneurship and increase employment outcomes did not have sustained impact in the medium-term, as business ideas and projects, despite significant results being shown in the short-term, were later abandoned. As the authors imply, other factors beyond entrepreneurship education, such as coaching and access to financing, need to be considered to have successful outcomes in the fostering of entrepreneurship.

The GEM Jamaica 2016/7 report highlights financial support, government policies, commercial and service infrastructure and physical infrastructure as areas of concern for entrepreneurial activities to improve. The report also highlights that not many initiatives exist to support highgrowth firms. Thus, despite the relationship that exists between entrepreneurship education and entrepreneurial intentions, the entrepreneurial-minded computing or engineering graduate may be demotivated from pursuing business if conditions such as these are unfavourable. As [27] suggests, consideration should be given to providing a supportive environment if longterm success is to be achieved. Notwithstanding, entrepreneurship education is necessary to strengthen future entrepreneurs who participate in the building of the economy and sustaining of our society [28] hence its importance should not be diminished, but enhanced through a broadened understanding of the conditions for entrepreneurial success.

\section{CONCLUSIONS}

The main objective of this article was to examine engineering and computing undergraduate students' perceptions of entrepreneurship education at the University of Technology, Jamaica, and whether it motivates them towards entrepreneurial intentions to start a business. The data was collected via a survey and the results analyzed using mainly descriptive statistics. Our results show that there is a general feeling among the students that the entrepreneurship education being delivered is insufficient to stimulate their entrepreneurial intentions. While motivations to start a business may exist in the students in other ways, more needs to be done to improve the level of education offered to promote entrepreneurship as a career path for students.

The limitations of this study are as follows. We only surveyed the computing and engineering students who are from one faculty in the university thus our findings therefore cannot be generalized to students from other fields of study. The findings, however, serve as a signal to the faculty leadership that the level of entrepreneurship educational

$17^{\text {th }}$ LACCEI International Multi-Conference for Engineering, Education, and Technology: "Industry, Innovation, And Infrastructure for Sustainable Cities and Communities", 24-26 July 2019, Jamaica. 
activities, both formal and informal, need to be increased to stimulate the human capital contribution that our technical students can make to the economy. We have also only examined only one factor influencing entrepreneurial intentions and have at this time, only used descriptive statistics to analyze the data. Other factors such as attitude, personality traits and social value could be investigated to examine their influence on entrepreneurial intentions, with inferential statistics used to further investigate relationships among the data.

Further research could examine whether the intentions among computing and engineering students exist at other higher education institutions within the country to provide a broader perspective on external policies and initiatives that could help to fund or stimulate students who are expected to engage in high growth businesses to stimulate economic activity in the country and region. Future studies are also recommended to examine the relationship between entrepreneurial intentions and actual behaviour so as to understand how to effectively close the human capital gap in the Latin American and Caribbean region.

\section{ACKNOWLEDGMENT}

The researchers thank the computing and engineering students who participated in this study.

\section{REFERENCES}

[1] Lederman, Daniel, Julián Messina, Samuel Pienknagura, and Jamele Rigolini (2014). Latin American Entrepreneurs: Many Firms but Little Innovation. Washington, DC: World Bank. doi:10.1596/978-1-46480012-2. License: Creative Commons Attribution CC BY 3.0

[2] Shane, S., \& Venkataraman, S. (2000). The promise of entrepreneurship as a field of research. Academy of management review, 25(1), 217-226.

[3] Esparragoza, I. E. (2009). Innovation, Design, Entrepreneurship and Leadership: Challenges for Latin America to Be Competitive in the Global Economy. In Proc. 7th Latin Amer. Caribbean Conf.(LACCEI) (pp. 7-8).

[4] Barba-Sánchez, V., \& Atienza-Sahuquillo, C. (2018). Entrepreneurial intention among engineering students: The role of entrepreneurship education. European Research on Management and Business Economics, 24(1), 53-61.

[5] Friar, J. H., \& Meyer, M. H. (2003). Entrepreneurship and start-ups in the Boston region: Factors differentiating high-growth ventures from microventures. Small Business Economics, 21(2), 145-152.

[6] Roberts, E. B. (1991). Entrepreneurs in high technology: Lessons from MIT and beyond. Oxford University Press.

[7] Doboli, S., Kamberova, G. L., Impagliazzo, J., Fu, X., \& Currie, E. H. (2010, October). A model of entrepreneurship education for computer science and computer engineering students. In 2010 IEEE Frontiers in Education Conference (FIE) (pp. T4D-1). IEEE.

[8] Zhang, Y., Duysters, G. M., \& Cloodt, M. M. A. H. (2014). The role of entrepreneurship education as a predictor of university students' entrepreneurial intention. International Entrepreneurship and Management Journal, 10(3),623-641. DOI: 10.1007/s11365-012-0246-Z

[9] Bird, B. (1988). Implementing entrepreneurial ideas: The case for intention. Academy of management Review, 13(3), 442-453.

[10] Davidsson, P. (1995). Determinants of Entrepreneurial Intentions. Paper presented at the RENT IX Workshop, Piacenza, Italy, Nov. 23-24, 1995.

[11] Ajzen, I (1991). The Theory of Planned Behaviour. Organizational Behaviour and HUman Decision Processes, 50, 179-211.
[12] Guzmán-Alfonso, C. \& Guzmán-Cuevas, J. (2012). Entrepreneurial intention models as applied to Latin America. Journal of Organizational Change Management, Vol. 25 Issue: 5, pp.721-735, https://doi.org/10.1108/09534811211254608

[13] Krueger, N., Reilly, M.D., \& Carsrud, A.L. 2000. Competing models of entrepreneurial intentions. Journal of Business Venturing 15(5-6): 411432.

[14] Shapero, A., \& Sokol, L. (1982). The social dimensions of entrepreneurship. Encyclopedia of entrepreneurship, 72-90.

[15] Pihie, Z. A. L., \& Akmaliah, Z. (2009). Entrepreneurship as a career choice: An analysis of entrepreneurial self-efficacy and intention of university students. European journal of social sciences, 9(2), 338-349.

[16] Lüthje, C., \& Franke, N. (2003). The 'making' of an entrepreneur: Testing a model of entrepreneurial intent among engineering students at MIT. R\&d Management, 33(2), 135-147.

[17] Devonish, D., Alleyne, P., Charles-Soverall, W., Young Marshall, A., \& Pounder, P. (2010). Explaining entrepreneurial intentions in the Caribbean. International journal of entrepreneurial behavior \& research, 16(2), 149-171.

[18] Jarrar, M., \& Anis, H. (2016). The impact of entrepreneurship on engineering education. Proceedings of the Canadian Engineering Education Association (CEEA).

[19] Piperopoulos, P. (2012). Could higher education programmes, culture and structure stifle the entrepreneurial intentions of students?.Journal of Small Business and Enterprise Development, Vol. 19 Iss: 3 pp. 461 - 483

[20] Souitaris, V., Zerbinati, S., \& Al-Laham, A. (2007). Do entrepreneurship programmes raise entrepreneurial intention of science and engineering students? The effect of learning, inspiration and resources. Journal of Business venturing, 22(4), 566-591.

[21] Obiero, D. O., Kiveli, D. M., Mule, D. L., Kyale, O. M., Etole, M. A., Kamanja, I. T., ... \& Gakuya, D. W. (2015). Factors Influencing Entrepreneurship among University Students In Kisumu County (Masters Thesis) Available online at http://erepository.uonbi.ac.ke/bitstream/handle/11295/93920/Obiero_Fact ors\%20Influencing\%20Entrepreneurship\%20Among\%20University\%20S tudents \%20In\%20Kisumu\%20County.pdf?sequence $=4$

[22] Watiri, M. S. (2012). Factors that influence student participation in entrepreneurship among university students; The case of Strathmore University undergraduate students (Master's Thesis). Retrieved from http://erepository.uonbi.ac.ke/bitstream/handle/11295/6795/Muigai_Fact ors\%20that \%20influence\%20student $\% 20$ participation $\% 20$ in $\% 20$ entrepre neurship.pdf?sequence $=1$

[23] Chipeta, E. M., Surujlal, J., \& Koloba, H. A. (2016). Influence of gender and age on social entrepreneurship intentions among university students in Gauteng province, South Africa. Gender and Behaviour, 14(1), 68856899.

[24] Mueni, K. V. (2016). Factors Determining Entrepreneurial Intentions among University Students in Kenya: A Case of USIU-Africa (Doctoral dissertation, United States International University-Africa). Retrieved from

http://usiuservicedesk.usiu.ac.ke/bitstream/handle/11732/2643/Kisolo.pdf ?sequence $=1$ \&isAllowed $=\mathrm{y}$

[25] Rice, R., \& Hancock, L. (2005). The mall intercept: A social norms marketing research tool. The Report on Social Norms, 4(7), 4-7.

[26] European Commission (2006). Entrepreneurship education in Europe: Fostering entrepreneurial mindsets through education and learning. Final Proceedings. Retrieved from https://ec.europa.eu/growth/content/entrepreneurship-education-europefostering-entrepreneurial-mindsets-through-education-and en.

[27] Alaref, J., Brodmann, S., \& Premand, P. (2019). The medium-term impact of entrepreneurship education on labor market outcomes: Experimental evidence from university graduates in Tunisia. The World Bank. Available online at https://files.eric.ed.gov/fulltext/ED594456.pdf.

[28] Lindner, J. (2018). Entrepreneurship education for a sustainable future. Discourse and Communication for Sustainable Education, 9(1), 115-127. DOI: https://doi.org/10.2478/dcse-2018-0009

$17^{\text {th }}$ LACCEI International Multi-Conference for Engineering, Education, and Technology: "Industry, Innovation, And Infrastructure for Sustainable Cities and Communities”, 24-26 July 2019, Jamaica. 